\title{
LISANDUSI OMAKIRJASTUSLIKE VÄLJAANNETE ARHIPELAAGI KAARDISTAMISEKS ${ }^{*}$
}

Kogumiku „Seilates sadamata” põhiteksti autor ja koostaja Kersti Unt ning kaaskoostaja Marja Unt on teinud kiiduväärt katse anda teatud kogupilt 1960.-1980. aastate almanahhideajast. Hannes Varblane on aga selle teose tutvustamise/arvustamise käigus teinud rea tähendusrikkaid vihjeid, mis paraku jäävad enamjaolt täpsustamata ja teabelises mõttes avamata. Näiteks toob $\mathrm{H}$. Varblane ära raamatus esitatud periodiseeringu, olles eelnevalt teinud paljuütleva märkuse: „On antud ka almanahhiliikumise periodiseering, kuigi eks sedalaadi sedastamine jääb tahes-tahtmata vaieldavaks" (Varblane 2013: 66). Kuid toodud periodiseeringu algusaasta 1968 pole mitte vaieldav, vaid lausa väär. Raamatu tekstist küll selgub, et esimene almanahh „Hees” ilmus 1967. aastal, kuid miskipärast periodiseering sellest aastanumbrist ei alga. Tähelepanu peaks äratama seegi, et teisel „Heesi” almanahhil on kaanel samuti aastaarv 1967. Tiitellehel aga ilmumisaastaks 1968, mis on muidugi formaalselt õige, kuid kaanel olev aastanumber märgib seda, et 1967. aastal oli sisuliselt kõik valmis (kaasa arvatud kaanevinjett ja siseillustratsioon) ja vaid masinakirjas paljunduse tegemine lükkas ilmumise järgmise aasta algusesse. Kas omab selline täpsustus tähendust? Sedavõrd ikka, et kinnitab veelgi enam tõika, et almanahhide aeg algas 1967. aastast. Lisaks aga peaks märkima, et kui otsida seoseid noorte vaimuilma ja hoiakute kujunemise ning Pariisi ja Praha 1968. aasta sündmuste vahel, mis kahtlemata olid olemas, kuid loomingulistes avaldustes suhteliselt raskesti jälgitavad, siis on hea teada, et "Heesi” teisest almanahhist pole tiitellehel olevast ilmumisaastast hoolimata mõtetki neid otsida.

\footnotetext{
* Vt ka Unt 2012, Varblane 2013.
}

Segadusseajav ja sisulise katteta on raamatu "Seilates sadamata" alapealkiri: „Omakirjastus okupeeritud Eestis". Kas omakirjastuslik tegevus algas siis almanahhidest ja 1960. aastate teisest poolest? Kindlasti mitte, siinkirjutaja tunneb perioodi vanima omakirjastusliku väljaande näitena üllitist 1947 . aastast, mis ei tähenda, et ei võiks leiduda vanematki. Probleem on selles, et teadaolevad vanemad omakirjastuslikud väljaanded pole almanahhid.

Siinkirjutaja tunneb esimese 1960. aastail ilmunud omakirjastusliku väljaandena $\mathrm{H}$. Hellati autorinime all üllitatud luulekogu „Neiro”. Läbimõeldult kujundatud kaanega, pagineeritud lehekülgedega, tiitellehel moto:

\section{Päike tõuseb ikkagi \\ idast! \\ Eks ole seal pimedam öö ja valusam valgusevaeg...}

Lisaks pühendus: „Pühendan ARTUR ALLIKSAARELE tänulikuna paljude paeluv-põnevate ekskursside eest luulevalda."

Väljaande sisuks on tervelt 99 luuletust, neist viimase all ajamääratlus: 12 . oktoober-21. november 1961. Oletades, et selle viimase, neljarealise „Unelaulu” sünnitusaeg nii pikk ei olnud (kuigi loomeprotsess on sedavõrd individuaalne ja salapärane, et selles surmkindel olla ei saa), siis peaks see tähistama küll poeedi (kelleks muidugi Henn-Kaarel Hellat) erakordset luulepalangut. Tosina aasta möödudes jõudis pisut enam kui kümnendik sellest ka kirjastuse Eesti Raamat editeeritud H.-K. Hellati luulekogusse „Vanad fookused”. Muudatusi on neis luuletustes "ametliku" väljaande tarvis tehtud minimaalselt, st absoluutse enamiku puhul üldse mit- 
te, kuid sellestki vähesest võib ehk teha teatud järeldusi (mis pole käsitletavad tingimata autori tahteavaldusena, eeskätt võib tegu olla ikkagi toimetuse/toimetaja nõudmistega): näiteks „Neiros” ilmunud kaherealine "Minu võitlus” on „Vanades fookustes" saanud pealkirjaks lihtsalt „Võitlus”. Siinkohal on vajalik rõhutada, et H.-K. Hellat oli ka almanahhideaja autorkonna hulgas, nimelt 1968. aastal ilmunud „Heesi” 4. väljaandes (st kolmandas „Heesi” almanahhis) on temalt kaks pala, teine neist 1962 . aastal loodud kolmkärakas ehk tertsskerts sonett „Pedantide peksupäev”. Viimane on hiljem ära toodud ka „Vanades fookustes", kuid ilma "Heesis” esineva seletuseta luuletuse vormilise isepära kohta, mistõttu viimane enamikule raamatu lugejaist arvatavasti õieti ei avanenudki, rääkimata sonetipärja rea- ja sõnatasandile taandava eripärase vormi autorist. Nimelt annab H.-K. Hellat „Heesis” teada, et kolmkärakas ehk terts-skerts sonett on teoreetiliselt rajatud ja esimesena praktiliselt tarvitatud Artur Alliksaare poolt. Kolmkärakas koosneb kümnest lausest, neist üheksa on kolmekaupa perioodideks jagatud, kümnes, resümeeriv aga koosneb eelmiste lausete esimestest sõnadest. A. Alliksaar seadnud veel tingimuseks, et lõpplause ei tohi enne valmis olla.

Ilma omakirjastuslike ühemehe-väljaanneteta pole võimalik saada pilti 1960. aastate luuleloo teisenemisprotsessist. Ainult almanahhide alusel kogu omakirjastuslikule tegevusele toetumine võib viia ka faktiliste eksimusteni. Nii postuleerib K. Unt, et „Thespis” I-V on praeguseks ainsana omakirjastuslikest väljaannetest trükis ilmunud (Unt 2012: 49). Ei, tänu Hasso Krulli valikule/koostamisele on ilmunud ka Jüri Üdi „Tiibadega raamatus" poeedi esikteos, Märt Laarmani poolt 1968. aastal linoollõikes plokkraamatuna editeeritud „Realistliku ingli laul” perfektselt, tervikuna (st täiel kujul: palgeleht, tiitel, vinjett, illustratsioonid ja tekstileheküljed) reprodutseeritult (Üdi 2007: 61-81). Kirjanike leksikonid (1995, 2000) kahjuks ei tunne "Realistliku ingli laulu” Jüri Üdi/Juhan Viidingu esikteosena, kuigi Toomas Liiv ei jätnud juba 1978. aastal kahtlust, et just see teos on autori esikraamat (Liiv 1978: 693). Ka H. Krulli koostatud „Kogutud luuletused” algab just selle luuletusega (Üdi, Viiding 1998: 29-43). M. Laarmani panus omakirjastuslike väljaannete tegemisse-editeerimisse plokkraamatute näol on 1960. aastate lõpul - 1970. aastate algul mitmekülgne ja rikkalik. Neist Friedebert Tuglase "Kahe taevalõigu" saamisloost on siinkirjutaja püüdnud anda ülevaate (Hain 2010), Käsu-Hansu nutulaulu (Hain 1993), Urvaste pastori Johann Gutslaffi poolt Vihtla Jürgeni suust 1644. aastal kirjapandud „Pikse palve” (Hain 2012) ja Jüri Üdi „Realistliku ingli laulu” (Hain 2007) puhul olen piirdunud põhiandmete esitamisega. Tolle plokkraamatute tegemise hilisperioodi (ta oli selle ala lähtemeistriks 1930. aastate teisel poolel) lõpetas M. Laarman Viivi Luige „Ülestunnistusega" 1972. aastal, mida ta ise nimetas tagasihoidlikult „raamatutegemise katseks”. Rõhutamist väärib asjaolu, et M. Laarman hoolitses selle eest, et kõik need omakirjastuslikud plokkraamatud oleksid toonase F. R. Kreutzwaldi nimelise Raamatukogu (tänane Eesti Rahvusraamatukogu) kogus, kus need on üldkasutatavalt kättesaadavad.

Pilt 1960. aastate omakirjastuslikest väljaannetest jääks tõsiselt puudulikuks ilma Kaljo Põllu teostatuna valminud Jaan Kaplinski luulevihuta, mis ilmus 1969. aasta märtsikuu alguses ja mille nimetuse kirjapilt kaane kohaselt on „Kolm lehekülge Tiiale Jaan”. Trükisõnas on seda fikseeritud ka teisiti, näiteks teose esmakordsel avalikul väljapanekul kunstniku 1971. aastal Tartu Kunstimuuseumis toimunud personaalnäitusel „Jaan Kaplins- 
ki luulevihik Kolm lehekülge Tiiale" (Põllu 1971). Väljaande initsiaatoriks oli J. Kaplinski ja teksti kohta tuleb allakriipsutavalt tähendada, et tegemist on nende luuletuste esmatrükiga. Edaspidi võib samu tekste näha poeedi mitmes hilisemas kogus, kuid ühe olulise erinevusega: „Kolme lehekülje” esimesel tekstilehel on kaks luuletust, mis järgnevalt moodustavad ühe, neist esimese avasõnade „Ja kui meri taandub” järgi nimetuse saanud luuletuse ja seda teatud redaktsiooniliste muudatustega (Kaplinski 1976: 35; 2000: 235). Niisiis, autori hilisemat tahet arvestades võib öelda, et „Kolme lehekülje...” sisuks on kolm luuletust, millest ülejäänud kaks - „Keegi ei saa mind panna tagasi kokku” ja "Olematus ulatub kõikjale” - on järgnevalt taasavaldatud samahästi kui muutmata kujul (Kaplinski 1976: 36, 45; 2000: 236, 245). Luuletuste tundeline tagapõhi juhtis K. Põllu romantilise, täpsemalt - rahvusromantilise kujundikasutuse suunas. Kaanemotiiviks pimetrükis rahvuslill rukkilill, kaanevinjetil piibeleht (rahvapärimustes armastuse ja õnne lill), vahetiitlitena hoburaudsõlg, rahvuslind suitsupääsuke ja kätepaari kujutis. Tekstiosas, mis teostatud sügavtrükitehnikas, kasutas K. Põllu ruunikirjast inspireeritud, paljuski kunstniku enda poolt kombineeritud šrifti. Seega võib näha „Kolme lehekülje..." kunstilises saates eelastet, mis viis kunstniku rahvuslikeks kujunenud sümbolite juurest arhetüüpsete, põhjarahvaste eluolu ning uskumuste pinnal tekkinud kujundliku ühisomandi poole ja sealt juba esiajaloolise loomepärandi märgilisuse uurimiseni.

K. Põllu kunstnikutegevusele omakirjastuslikes väljaannetes on raamatus „Seilates sadamata” viidatud „Kolme mehe laulude" kaanepildi esitamisega. Raamatu esiletõusvaks tunnusjooneks ongi rikkalik saade, mis haarab almanahhidest reprodutseeritud tekste, illustratsioone ja kaanepilte. K. Põllu puhul on märgilisemaks küll kaanepildist napimate vahenditega - pimetrükis teostatud siseillustratsioonid, mis põhinevad võimlemisharjutustest ja kaardimängust eputava moelabasuseni ulatuval kujundite kombineerimisel, esimene popkunsti näide meie kunstiväljal üldse. Kuna ühise nimetaja leidmine otseselt luuletustest lähtuvate kujundite pinnalt oli nii erinevate autorite puhul nähtavalt väheviljakas, võttis kunstnik lähtekohaks üldisema hoiaku, mis oli solidaarne luuletajate teisitimõtlemise, pealesurutud kultuurimalli suhtes kontrakultuurilise manifestatsiooniga. Säärane valmiskujundite kasutus, nagu seda näeme „Kolme mehe laulude" kunstilises saates, leidis arenduse K. Põllu aastail 1969-1972 loodud vabagraafikas.

Kahjuks pole raamatus „Seilates sadamata" reprodutseeritud almanahhide kaantest ja siseillustratsioonidest peale autorite nimetamise kuigivõrd juttu. On küll õigusega märgitud, et almanahhide avaldamise algperioodil ilmutati suuremat hoolt väljaannete kujundusliku külje suhtes ja viidatud on ka olulisele tunnusjoonele, mida $\mathrm{H}$. Varblane on pidanud eriti rõhutamisväärseks: „Algperioodil ühendas see nii kirjanduse, muusika kui ka kunsti" (Varblane 2013: 67). Kindlasti on see nii, kuid täpsem oleks öelda, et algperioodil olid sellised seosed tihedamad, kuid ei puudunud hiljemgi. Näitena saaks tuua just almanahhiliikumise hilisperioodi, mida ilmestasid ka sellised nimed, keda nende hilisema tegevuse peasuunamuutuse tõttu on õigusega arvatud esmajoones kujutavate kunstnike kilda, kuid kes siis osalesid aktiivsete sõnakunsti viljelejatena: Leonhard Lapin, Urmas Mikk, Andrus Rõuk, visalt nii kunstnikuna kui ka kirjanikuna pildil püsiv Kai-Mai Olbri. Seejuures eakaaslased U. Mikk (1957-1999) ja A. Rõuk (snd 1957) jõudsid kiiresti ja pea üheaegselt, mõlemad 1979. aastal, ka Loomingu veergudele 
(Mikk 1979; Rõuk 1979). Neist esimene on kahe raamatu autor (Mikk 1986; 2000; teine teos ilmus küll postuumselt, illustratiivseks saateks autori kunstiteoste reproduktsioonid) ja A. Rõuk tuletas suhteliselt hiljuti raamatuvormis meelde enda tegevust luuletajana aastail 1976-1980 (Rõuk 2000). L. Lapin avaldas kvintessentsi Trapeeži-luulest juba kakskümmend aastat tagasi (Trapeež 1993) ja tema seni viimane Trapeežiga seotud trükis täiendab ja avab toonase sõpruskonna tegevust, mis haakus ka almanahhide tegemisega (Trapeež 2012). Samas on L. Lapin ka laiendanud Trapeeži loomingut, tõstes mõned almanahhides teise pseudonüümi all (näiteks Leopold Propeller) ilmunut Trapeeži teoste hulka.

Mida edasi 1980. aastatesse, seda enam leidub almanahhides pseudonüümide all avaldatut ja raamatu „Seilates sadamata" üheks oluliseks lisaks on kahtlemata nende pseudonüümide ulatuslik avamine. Viimane näitab mõne teadaoleva almanahhiautori tegutsemismahtu seni teadaolevast ehk mahukamana (näiteks on avaldatud viis Tõnn Sarve pseudonüümi), täpsustab paari varjunime taga oleva kahe-kolmeliikmelise kollektiivi ning aitab meenutada lahkunute Juhan Paju (1939-2003), Ott Arderi (1950-2004) ja Jaanus Tamme (1957-2010) loomingulist käekäiku. Selle töö keerukusest annab märku küsimärgistamine ja seda mitte ainult manalamehe Erik Udami (1938-1990) puhul, vaid lõplikult vastamata jääb, kas K. V. on ikka Indrek Hirve pseudonüüm või kuulub kellelegi teisele.

I. Hirve on raamatus tunnustavalt nimetatud almanahhi „Salong” (1978) illustraatorina ja see on teenitud esiletõstmine. Kuid üldiselt puudutatakse teoses „Seilates sadamata” kujundusküsimusi sporaadiliselt. Selline konstateering pole tehtud kriitilises plaanis - kirjandusteadusliku sihiasetusega teoselt ei saa enamat nõudagi. Kahjuks jääb seetõttu aga avamata seos uuemate kirjanduslike ning kunstisuundumuste vahel, milline põimumine ilmnes eriti selgelt almanahhiliikumise esimesel perioodil, mil säärased seosed ei avaldunud mitte ainult üllitiste illustratiivses saates, vaid ka nende sisus. 1960. aastatel mõjusalt kunsti uuendusliikumist edendanud grupi ANK '64 liikmetest olid otseselt seotud almanahhiliikumisega Tõnis Vint, Aili Vint, Jüri Arrak ja Vello Tamm, Tartu rühmitusest Visarid (mis tegutses aastail 1967-1972) aga Kaljo Põllu, Enn Tegova, Rein Tammik ja Peeter Urbla.

Tõnis Vint lõi „Heesi” almanahhide kujunduse, andes neist esimesele süsteemse, läbitöötatud maketi ning pannes erilise rõhu ka kunstiosale ja seda mitmes plaanis. Esiteks nähes ette almanahhide pildilise saatena originaalgraafilisi, linoollõike tehnikas teostatud (mis oli optimaalne võimalus nende kvaliteetseks esitamiseks) töid. Teiseks plaanides kunsti tarvis sõnalise osa, mis pidi koosnema nii tõlkematerjalist kui ka omakirjutistest, ning kolmandaks püüdes kunstilis-kujunduslike võtetega juhtida lugeja-vaataja tähelepanu mõnele kirjanduslikule palale. Täielikult ja süsteemselt rakendatuna teostusid need plaanid vaid esimeses almanahhis, kuid määrasid põhijoontes ka järgmiste ülesehituse. Esimeses almanahhis on palade pealkirjad kas musta või punasega alla joonitud. Kirjandusliku osa keskele paigutatud Astrid Reinla luuletus "Minek”, mille finaali Ristikivi-parafraas rõhutab kodusolijate kodumaatust, on esile tõstetud paljundusega läbi punase kopeerpaberi.

Sellisena ainukeseks jäänud pildilise lisa nimetuseks esimeses almanahhis on Galerii ANK '64, mis koosnes kahest teosest: Aili Sarve „Pöörised” ja Jüri Arraku „Käed”. Neile on antud ka sõnaline selgitus, mis almanahhis on anonüümne, kuid mille autoriks on Tõnis Vint. Nii need linoollõiked kui ka tekst 
Galerii ANK' 64 juurde on raamatu reproduktiivses lisas ära toodud, kuid viitamata on jäänud nimele, mille all me esimesena nimetatud linoollõike autorit kunstnikuna tunneme - Aili Vint. Kunsti käsitleva sõnalise põhiosa moodustavad avanumbris tšehh Miroslav Lamaši artikkel „Kunstiline kujund ja ruum" ning Tõnis Vindi kirjutis pealkirjaga „Aknad”, mis jäi järgnema. Viimase põhisisuks oli vaade nüüdiskunstile Vassili Kandinsky teoreetilistest seisukohtadest lähtuvalt. Paraku selgus, et kolme erineva paberi kasutamine almanahhis ning tavalisele masinakirjale punase lisamine ja pealkirjade käsitsi allajoonimine venitas kokkuvõttes niigi aega- ja vaevanõudvat paljundamisprotsessi veelgi. Esimeses almanahhis on kolofoonil nimeliselt ära toodud ka paljundajad (A. Koltmann, T. Heinapu, S. Nebel), järgmistes on sellest loobutud ning kujundust ka mõneti lihtsustatud.

Teise „Heesi” almanahhi kujundajaks oli kunstiinstituudi graafikaeriala üliõpilane Illimar Paul, kes peajoontes lähtus Tõnis Vindi mallist. Kunstiosas jätkus Tõnis Vindi kirjutis „Aknad”, tõlkeartikliks Gérald Gassiot-Talabot' „Mittemaalilistest tehnikatest kunstis”, mõlemad jäid järgnema. Paraku järgmine ja viimaseks jäänud „Heesi” almanahh ilmus ilma lubatud järgedeta. Teises almanahhis loobuti ka Galeriist ANK '64, nii kaanevinjeti kui sisepildi autoriks oli Illimar Paul. Viimase almanahhi kujundajaks oli taas Tõnis Vint, sisepiltide-linoollõigete autoriteks aga kunstiinstituudi graafikaeriala silmapaistvad üliõpilased Naima Neidre ja Marje Üksine. Seega „Heesi” eesmärk polnud pildilise saate osas mitte niivõrd küpsete kunstiideede esitamine, kuivõrd tõusvate annete tutvustamine, nende kaasamine alternatiivkultuuri avaldustesse.

1960. aastate (ümber)kujuneva kultuurisituatsiooni iseloomustamiseks tuleb vaadelda ka tõlkekirjandust, milles peegelduvad teiseneva kirjandusprotsessi mõjulätted. Mart Velsker on seda kujunemisaega jälgides leidnud: „Kirjanduses levib mitmeid jooni, milles kajastub Lääne ja Eesti ühisosa - seda võib kinnitada Rummo või Isotamme publitsistliku hoiakuga vabavärss, Undi huvi sotsiaalsete müütide uurimise ja lammutamise vastu, luule ja folklaulu puutepinna suurenemine, Kaplinski, aga ka mitme teise süvenemine zen-budismi - ja ega näited sellega lõpe" (Velsker 1999: 1215). Tema poolt märgitu ei kajastu mitte ainult almanahhides avaldatud originaalloomingus, vaid ka neis esinevates tõlgetes. Viimased ei ole seni almanahhiliikumise käsitlustes kuigivõrd tähelepanu pälvinud, kuid aega ning huvisuundi peegeldavad need mitmeti.

Mis puutub „Heesi” almanahhe, siis neis on seni nagu märkamatuks jäänud konkreetsele luulele tähelepanu pööraja pioneeriroll, mis avaldub nii originaalloomingus (Raul Meel teises ja kolmandas almanahhis) kui ka väliseeskujude esitamises-tõlgitsemises. Algab see kohe esimeses almanahhis kirjandusliku müstifikatsiooni piiril seisva viguriga Joel Sanga poolt: ta avaldas Christian Morgensterni „Kala öölaulu” täpselt sellisel kujul, nagu too oli luuletaja 1905. aastal ilmunud kogus „Võllalaulud” („Galgenlieder”) - mõttekriipsudest ja sulgudepooltest koosneva kujundina. Müstifikatsioonihõngu lisandas enese märkimine tõlkijaks ja joonealune märkus: „Seda luuletust on varem tõlkinud ka Jaan Kross ja Andres Ehin, kuid kahjuks pole nende sugugi mitte halvemad tõlked trükki pääsenud.” Konkreetse luule ajaloolisele protoeeskujule viitamisele järgnes teises almanahhis juba Raul Meele originaallooming ning kolme selle meil alles vähetuntud ala elava klassiku näidete esitamine. Neist Dom Sylvester Houédard (1924-1992; tema nimi almanahhis oli ebatäpne, mis on kahjuks kandunud siit hiljem 
ka meie trükisõnasse) on esindatud luuletusega „Rock Sand Tide” nii originaalversioonis kui ka eestikeelses tõlkes-kujunduses. Kahjuks selle õnnestunud paralleelnäite eestindajat pole märgitud. Ülejäänud kaks konkreetse luule meistrit olid tšehh Jan Burka (1924-2009), kelle põhiline õppimis- ja töötamiskoht oli Kanadas, ja austerlane Ernst Jandl (1925-2000). Viimase, Viini Gruppi (Wiener Gruppe) kuulunud kuulsuse loomingut on hiljem eestindanud Jaanus Vaiksoo. Viimaseks jäänud „Heesi” almanahhis oli välisautoriks prantslane Henri Chopin (1922-2008), kelle teosest „Luule alfabeet” tarvitses tõlkimist ainult pealkiri. Sellele järgnes almanahhis näide Raul Meele loomingust. Kokkuvõttes väikesemahuline, kuid läbimõeldud esitus konkreetse luule edenemisest ilmalaanes ja selle algusest meil Raul Meele näitel.

Almanahhide kõrval ilmus „Heesi” väljaandena Toomas Vindi luulekogu „Suitsupilvedest unistus”. Selles pakub ta mitu näidet enda katsetustest konkreetse luule vallas, millest stiilipuhtamat „kirjutusmasinaluulet” esindab pala „Must auk ja valge auk”. Äramärkimist väärib ka luulekogu kunstiline saade, mis koosneb kaanevinjetist, tiitelpildist ning leheküljelistest kompositsioonidest „Kahekesi” ja „Neljakesi”, mis teostatud Toomas Vindi poolt linoollõike tehnikas. K. Unt on "Heesi” üllitiste kohta väitnud: „Neist esimene, teine ja neljas on kokku pandud almanahhidele omasel moel, kolmanda numbri on kirjastanud, kirjutanud ja ka illustreerinud üks „Heeside” viljakamaid kaasautoreid Toomas Vint" (Unt 2012: 28-29). Kirjastamise kohta on eeltoodud postuleering siiski vaieldav luulekogu esilehekülje pöördel on selgesõnaline kinnitus: „Heesi” väljaanne 3, mis tähendab seda, et Toomas Vint oli sedapuhku distantseerunud Noorte Autorite Koondisest, kuid mitte „Heesist”. Kõik kolm almanahhi kannavad aga kolofoonil enne „Heesi” nimetamist ka viidet NAK-ile. H. Varblane, viidates almanahhiliikumise algperioodi eestvedajaile, väidab, et: „Tallinlaste puhul tuleks samast ajast esile tõsta Toomas Vindi juhtrolli" (Varblane 2013: 67). Tahtmata pisendada Toomas Vindi osa, peaks siiski selle liikumise algatajatena-korraldajatena päris võrdväärseina nimetama ka Tõnis Vinti ja Jaak Jõerüüti.

Almanahhide sisulise hindamise puhul ei saa jätta arvestamata kirjandusliku uudisloomingu kõrval avaldatut: tõlkeid, klassikute töid (näiteks Eduard Vilde „Tokerjad” „Heesi” kolmandas almanahhis) ja muud (näiteks 1965. aastal tehtud intervjuud Kalju Lepikuga esimeses „Heesis”) - kõik sellesarnane oli sünkroonajas paljuütlev, ajakajaline, säärased valikud polnud juhuslikud. Niisugused seosed nõuavad täna juba seletamist, toonaste asjaolude ja sündmuste meenutamist. Eeltoodud üldsõnalist sedastust püüaksin avada kahe väikese näite varal, mis on mõlemad võetud 1969. aasta märtsis Tallinnas ilmunud sangviinikute almanahhist „Magasin”.

Vaadeldes 1960. aastate luulet, on mitmed kirjandusteadlased, nende seas ka K. Unt, põhjendatult märkinud arbujate ja eeskätt just Heiti Talviku mõju luule teisenemisprotsessile. „Magasin" kinnitab arbujatelembust sellega, et almanahhi avalöögiks oli valitud kaks Talviku luuletust. Kuid eriti ajamärgiline, arvestades keskkonnamuutusi, on nende luuletuste valik. Meenutamist vajab, et $\mathrm{H}$. Talviku luule oli Eestis sõjajärgselt ilmunud trükisõnas esimest korda esil 1967. aastal ilmunud Paul Rummo koostatud antoloogias „Eesti luule”. Järgmisel, 1968. aastal (seda raamatu tiitliandmete järgi, faktiline ilmumine jäi ilmselt 1969. aasta algusesse) jõuti „Väikese luuleraamatu” sarjas H. Talviku luulekogu avaldamiseni (koostaja August Sang), mis sisal- 
das ka kolm näidet poeedi hilisluulest - st peale tema teist (ja viimast) eluajal ilmunud kogu „Kohtupäev” loodut. „Magasini" on valitud näited hilisloomingust, mis mõtteliselt täiendavad nende kolme äsja avaldatud luuletusega markeeritud pilti. Esimene neist, „Loojak”, on jäänud almanahhis küll daatumita, kuid oli kirjutatud 1939. aastal ning leidnud tunnustavat esiletõstmist pagulaste Ants Orase ja Aleksander Aspeli poolt. Neist esimene nimetab saatesõnas H. Talviku „Kogutud luuletustele” (Oras 1957) „Loojakut” luuletaja pühaklikuks vaimseks testamendiks; teine artiklis $\mathrm{H}$. Talvikust konstateerib kokkuvõtvalt: "„Loojakus” on aga kõik Talviku luule põhiteemad ta lunastava tõe valguses ühinenud" (Aspel 1958: 23). Niisugune avaluuletuse valik näitab nii Eestis varem avaldamata H. Talviku luule kui ka pagulaskirjasõna tundmist. Teisena „Magasinis” ilmunud luuletuse „Kaks kutset” kirjutamisaeg jääb oletatavasti 1942. aasta teise poole ja 1944. aasta alguskuude piirdeisse ning laiemale lugejaskonnale avanes taust kirjaniku sellisele mõtteseadele alles 2004. aastal, mil Karl Muru koostatud Talviku-raamatus „Legendaarne" leidis avaldamist üks poeedi mõtisklus (või kirjakontsept) 1944. aasta algusest (Talvik 2004: 191-192). Tagantjäreletarkus tõstatab küll hüpoteesi, et sangviinikutele pidi tuttav olema H. Talviku pärand (mis siis püsis Betti Alveri hoolsal hoiul).

Teise autorina esineb „Magasinis” Jaan Tooming, keda ükski almanahhidest kirjutaja pole vajalikuks pidanud ära märkida. Õigusega, sest tema kolmerealine tekst, mis autori minapildina annab teada, et ta on kala, kes ujub vees, kellel on natuke külm ning kes on vait, peegeldas mingis mõttes ehk siis teatud osa noorharitlaste seas levinud mõttemalli, kuid ei iseloomustanud kirjapanijat ennast. Ehk teisisõnu - loomingulise aktina poleks need read pidanudki almanahhi veergudele jõudma, kuid neil oli ajas teine, märgiline tähendus. Sest vaevalt kaks kuud enne „Magasini” ilmumist oli Kirjanike Maja saalis toimunud eriliseks osutunud sündmus - Jaan Toominga initsieeritud ja lavastatud (kaaslavastaja Evald Hermaküla) Gustav Suitsu loomingule pühendatud õhtu „Ühte laulu tahaks laulda", mille sõnum osutus paljuütlevaks ning meeldejäävaks. Nii meeldejäävaks, et esitatust osa saanud Jaak Jõerüüt on nelikümmend neli aastat hiljem teinud sellest niisuguse kokkuvõtte: „Kinnine Vene aeg oli, aga need hääled olid vabad, isegi kui nad meeleheites kisendasid. Need hääled ja need lennud olid vabad" (Jõerüüt 2013: 523).

J. Toominga mõne kirjarea avaldamine oli kiire ja otsene reaktsioon tema initsieeritud erilisele kultuurisündmusele. Kahe seni Eestis avaldamata H. Talviku luuletuse almanahhis esitamine sai kultuurisündmuseks.

Aeg, ängid ja lootused peegelduvad kogu omakirjastuslikus liikumises, kuid just „Magasini” siinkohal näiteks toomisel on seos nii K. Undi kui ka H. Varblase poolt kirjapanduga. Neist esimene väitis 1999. aastal, et „Magasinis” on olulisim „Paul-Eerik Rummo hinnangut andev saatesõna" (Unt 1999: 1235). Võib-olla nii, kuid kui proosat esindavad selles väljaandes niisugused nimed nagu Mati Unt, Vaino Vahing ja Rein Saluri, luulet Jüri Üdi ja Joel Sang, väljapaistvate välisluuletajate (Guillaume Apollinaire, Thomas Stearns Eliot, Allen Ginsberg) tõlkijaiks on aga sellised selle ala taidurid kui Ain Kaalep, Jaan Kaplinski ja Joel Sang, siis peaks olulisust kui otsustuse alust, kriteeriumi täpsustama ja hinnangut põhjendama. Seejuures P.-E. Rummo kirjutis (mis pole saatesõna, nagu eelpool toodud tsitaadist nähtub, vaid sünkroonajas parim ülevaade esimeste almanahhide kohta) näitas, et noorte uudislooming pakkus asjalikku arutlusainet, võib- 
olla osutus siis „Magasin” eelkäijatest kehvemaks? Kindlasti mitte ja seda kinnitab küllaltki kriitilise H. Varblase hindav repliik: „Allakirjutanule endale meeldis vägagi algaegade "Magasin"” (Varblane 2013: 68).

Tõsi, raamatus „Seilates sadamata” annab K. Unt teada, et P.-E. Rummo eelnimetatud kirjutis kandis pealkirja „Kirjanduslikeks kihermeiks tellitud” ja oli algselt mõeldud ajakirjale Noorus, kus see siiski avaldamist ei leidnud, ning siis avalikustas autor selle almanahhis (Unt 2012: 28 jj). Veelgi enam - raamatu lisas on see tekst tervikuna ära toodud. Rõhutamist vajab, et ülevaade haarab „Heese” ja kahte „Marmi” ning ka tulevikuvisiooni. Viimase kohta ütleb P.-E. Rummo sealsamas: „See ennustamine oli muidugi ainult mäng vormelitega, sest arvestasin vaid nähtuste sisemisi reegleid, nagu ma neid kujutlen, ja mitte reaalseid mängijaid ja väliseid olukordi." Kuid just sealtmaalt, kus lõpeb P.-E. Rummo ülevaade, hakkasid välised olukorrad kiiresti muutuma, mis reaalselt tõi kaasa nii mängijate vahetumise kui ka sisemiste reeglite muutumise, millele ka P.-E. Rummo erksalt reageeris, kuid sellest allpool.

Johnny B. Isotamm teatas 1968. aastal ilmunud almanahhis „Marm” kategooriliselt:

\section{MINU LAULUD POLE}

trykkimiseks

kassettide kirevaselgses hermafrodiitsuses

ega kirjandusajakirjade vanaksläinud kahjutus impotentsuses ...

See oli kindlasti siiras avaldus, mis ei iseloomustanud ainult nende ridade autori hoiakut, vaid ilmselt peegeldas paljude almanahhide algatajate seisukohta. Ometi toimusid selles vallas suhteliselt kiired muudatused, mille üheks näiteks on juba 1969. aasta veebruaris ajakirjas Looming ilmunud viis Johnny B. Isotamme luuletust. Huvi almanahhide vastu oli suur, neid anti käest kätte, paljudel jäi tutvumisaeg napiks, see-eest kirjutati ümber/paljundati üksikuid luuletusi ja kirjutisi, mida omakorda sõpruskonnas levitati. Almanahhide sisuga tutvus sadu inimesi, kellest absoluutne enamik oli ühiskonnas ja loomingulises tegevuses ilmnevas tardumusprotsessis muutusi ihkavad noored. Loomingu selle numbri tiraaž, milles avaldati Johnny B. Isotamme luuletused, oli 10200 eksemplari, lugejaid aga paarkümmend tuhat. Poeet võitis tuhandeid poolehoidjaid ja sai sadu vaenlasi, kellest osa ei mõistnud tema sõnumit, väiksem, kuid mõjukam tegi sellest ja muudest säärastest avaldustest selgesuunalised järeldused.

Seda üllatavam on võimupoolsete sammude aeglane start ülaltpoolt kontrollimatu vaimuvabaduse ohjeldamisel. Viimast pole teoses „Seilates sadamata” peetud oluliseks märkida, kuid almanahhide retseptsiooni paremaks kirjeldamiseks peaks teatud üksikasjadega arvestama, milleks on kuupäevalise täpsusega pidepunktid andnud toonane Kirjanike Liidu sekretär Vladimir Beekman. ${ }^{1}$

Nimelt jõudis esimene almanahhe puudutav häiresignaal Eestimaa Kommunistliku Partei Keskkomiteest Kirjanike Liitu alles 14 . novembril 1968, seega pisut enam kui aasta pärast esimese almanahhi ilmaletulekut: „Helistas Utt ${ }^{2}$ küsis, kas tean midagi lähemat „Heesi” ja „Marmi” kohta; et ma ei teadnud, siis

${ }^{1}$ Vladimir Beekman (1929-2009) oli aastail 1968-1971 ENSV Kirjanike Liidu juhatuse sekretär, kuid tegelikult organisatsiooni tegevjuht, sest Kirjanike Liidu esimees Juhan Smuul (1922-1971) oli selleks ajaks tegevjuhtimisest taandunud.

${ }^{2}$ Olaf-Knut Utt (1929) oli aastail 19641969 EKP Keskkomitee teaduse ja kultuuri osakonna juhataja asetäitja ja 1969-1983 samas kultuuriosakonna juhataja. Kirjanike Liidu liige 1962. aastast. 
palus välja selgitada ja teatada" (Beekman 1994: 728). Edasi arenesid asjad kiiremini ja pisut vähem kui kuu aega hiljem, 11. detsembril 1968 oli arutlusjärg EKP KK kultuuriosakonnas: „Paar tundi Uti juures koos Sikemäe, Ehini ja Viidinguga, ${ }^{3}$ kõne all „Hees”. Otsustati tugevdada NAK-i sidemeid „Heesiga”, mis on praegu grupiväljaanne. Runnel ja Paul-Eerik olevat Paide Kultuurimajas esinedes ,igasugust jama” ajanud, kultuuritööd ja kirjandust tühjaks pidanud, nomenklatuurse ajakirjanduse tribüüni kitsaks ja kirjanduselu sumbunuks arvanud ning „Heesi” ja „Marmi” lehvitades kutsunud selliseid „üldrahvaliku tribüüni” näiteid rohkendama. Provintsirahvas olla päriselt jahmunud. Utt väljendas muret selle üle, et esinemas käivad enamjaolt ikka samad noored mehed, kes „naljakaid tõekspidamisi” esitavad. Arvas, et seda peaks korrigeerima" (Beekman 1994: 730).

Otsustav järg tuli 24. veebruaril (sic!) juba EKP sekretäri juures: „Kaks tundi Lentsmani ${ }^{4}$ juures „Marmi” ja „Heesi" asjus. Ikka põhiseisukoht: tuleb ära lõpetada, muidu on varsti kõik kohad sihukesi väljaandeid täis ja mis me siis peale hakkame? [---] Nagu ikka, keelas Lentsman rääkimise, et see on KK nõue - eks võõraste kätega ole ikka hõlpsam neid va kastaneid tulest välja tirida..." (Beekman 1994: 733). Almanahhitegijatel oli muidugi ükskõik, kelle „käed” olid mängus, nad tegid 3. märtsil 1969 veel katse siiski NAK-i egiidi all oma asja edasi ajada: „Istusime poolteist tundi Ehini, Toomas Vindi ja Imme Vii-

${ }^{3}$ Ilmar Sikemäe (1914-1998) oli sel ajal Kirjanike Liidu proosakonsultant, NLKP liige 1945. aastast, Kirjanike Liidu liige 1949. aastast. Andres Ehin (1940-2011) oli kultuurilehe Sirp ja Vasar peatoimetaja asetäitja, NLKP liige 1968. aastast. Ine Viiding (1933-1990) oli EKP Keskkomitee teaduse ja kultuuri osakonna instruktor, NLKP liige 1963. aastast.

${ }^{4}$ Leonid Lentsman (1912-1996) oli aastail 1964-1971 EKP Keskkomitee sekretär. dalepaga. Nad käisid jonnakalt peale almanahhi väljaandmise asjus" (Beekman 1994: 733). ${ }^{5}$

Noortele sai selgeks see, mis V. Beekmanile oli teada juba enne „pooltteist tundi": NAK-i kattevarjuna enam kasutada ei saa, almanahhide väljaandmist hakatakse käsitlema illegaalse tegevusena, mille eest vastutus on isiklik, ja et edaspidi võib karta repressioone nende suhtes, kes almanahhide tegemist teo ja sõnaga toetavad. Viimased ei jäänud tulemata, kuna almanahhiliikumine jätkus. Muutusid küll almanahhid ise: vähenes luule osakaal ja kasvas proosa ning publitsistliku suunaga kirjutiste hulk, muutus kirjutajate koosseis - osa senistest tegijatest taandus almanahhides esinemisest, juurde tuli uusi jõude, suurenes pseudonüümide all esinejate hulk. Mis aga peamine - kõigis žanreis kirjutatus avaldus varasemast sirgjoonelisem, sõnaselgem vastuhakk valitsevale survele. Kõik muudatused kokku ei suurendanud, vaid pigem piirasid avaldatu kunstilise taseme tõusu ning suurenes seesuguste almanahhide osa, mille sisu avamiseks ei piisa kirjandusteaduslikust võtmest ja lisaks tuleb kasutada sotsiaalteaduste muukraudu. Ehk teisisõnu - almanahhide ja üldse omakirjastusliku produktsiooni ühiskondliku tähtsuse ja tähenduse analüüsimiseks ja hindamiseks peaks kasutama eri valdkondade asjatundjate koostööd.

P.-E. Rummo ülevaates „Kirjanduslikeks kihermeiks tellitud” esitas almanahhikirjandust vaagides hoiatuse jõuetu kaksikkultuuri (ehk kahe kultuurituse) eest ning märkis, et professionaalsuse mõiste argipäevaselt kattub avalikkuse mõistega, mis väljendub kirjanike seotuses ametivõimudega,

5 Toomas Vint (1944), NAK-i liige, töötas ETV-s režissööri assistendina. Imme Viidalepp (1947-2006), NAK-i liige, esimese ja kolmanda „Heesi” almanahhi toimetuse liige; hiljem tuntud graafik ja kunstiõpetaja. 
alluvusena nendele. Muutunud olukorras toimusid teatud muudatused ka teravapilgulise analüütiku P.-E. Rummo hoiatustes ja soovitustes. 1973. aasta kevadel Tartus ilmunud almanahhis „Vigilia” II kirjutamise-avaldamise probleeme vaagides hoiatab ta kirjutajaid nii demonstratiivse lojaalsusega kaasnevate isiklike hüvede meelituse kui ka märtrikrooni taotlemise eest. Pidades aga vajalikuks lisaks rõhutada: „Ilmumise kohta see peaaegu ei käi: legaalsus või illegaalsus pole kategooriad, mida siin kohaldada saaks. Kuivõrd üks kirjanduslik tekst on suhteliselt iseseisev nähtus, pole kuigi oluline, milliste tekstide keskel või kelle häälekandja kaante vahel ta paljundatult ilmub. Oluline on, et kui üldse, siis ilmuks ta

\section{Kirjandus}

As pe l, Aleksander 1958. Heiti Talviku isiksus ja luule. - Mana, nr 4, lk 7-24.

B e e km a n, Vladimir 1994. Kirjanike Liidu logiraamat. - Keel ja Kirjandus, nr 12, lk 727-742.

H a i n, Jüri 1993. Lisandusi ilmunule. Keel ja Kirjandus, nr 1, lk 45-46.

H a i n, Jüri 2007. Ruumist lennuharjutusteks. - Sirp 30. III, lk 24.

H a i n, Jüri 2010. Kahe taevalõigu lugu. Friedebert Tuglase ja Märt Laarmani ühisteest ja koostööst. - Muutliku vikerkaare all. Tallinn: Underi ja Tuglase Kirjanduskeskus, lk 14-25.

H a i n, Jüri 2012. Võõrsile ja võõrsilt. Ajutiselt ja jäädavalt. - Varjust välja! Tuntud kunstnike vähetuntud teoseid Underi ja Tuglase Kirjanduskeskuse kunstikogust. Tallinn: Underi ja Tuglase Kirjanduskeskus, lk 37-38.

J õ e r ü ü t, Jaak 2013. Härra Dussmanni raamatuäri. - Looming, $\mathrm{nr} 4$, lk 520528. sellisel kujul, nagu autor ta käest andis." Selle olevikuolukorda arvestava ja tulevikku suunatud mõttekäiguga osa sel hetkel almanahhiliikumises kaasalööjaid ilmselt nõus olla ei saanud. Kuid poeet P.-E. Rummo oli juba 1968. aastal legaalses väljaandes avaldanud luuletuses „Saatja aadress” rea: „Su saatus on su veendumuste ainus väljendus" (Rummo 1968: 1832), millele oli ilmselt peatselt valmis alla kirjutama absoluutne enamik Eestis omakirjastusliku tegevusega liitunuid.

JÜRI HAIN

Kaplinski, Jaan 1976. Ma vaatasin päikese aknasse. Tallinn: Eesti Raamat.

K a p li n s ki, Jaan 2000. Kirjutatud. Valitud luuletused. Tallinn: Varrak.

L i i v, Toomas 1978. Juhan Viidingu luule. - Keel ja Kirjandus, nr 11, lk 693695.

M i k k, Urmas 1979. Tagasitulek. - Looming, nr 7, lk 999-1000.

M i k k, Urmas. 1986. Eraelust akadeemilise eluni. Tallinn: Eesti Raamat.

M i k k, Urmas 2000. Linnu süda. Järelejäänud tekste 1977-1985. Tallinn: Urmase Sõbrad, 2000.

Or a s, Ants 1957. Heiti Talvik - luuletaja ja tema missioon. - Heiti Talvik, Kogutud luuletused. [Stockholm]: Vaba Eesti, lk 5-22.

Põllu, Kaljo 1971. (Näituse kataloog). Tartu: Tartu Riiklik Kunstimuuseum, lk 35 . 
R u m m o, Paul-Eerik 1968. Saatja aadress. - Looming, nr 12, lk 1830-1832.

Rõ u k, Andrus 1979. „kontrolli kumme suunatulesid”, „uus aasta vanad probleemid". - Looming, nr 9, lk 1256-1257.

R õ u k, Andrus 2000. Vapp lipp pealinn. Luulet 1976-1980. [Autori illustratsioonid.] Tallinn: Virgela.

T a lvi k, Heiti 2004. Legendaarne. Koostanud Karl Muru ja Hando Runnel. Tartu: Ilmamaa.

Tr a p e ě̌, Albert 1993. Sitased seitsmekümnendad. Ebatsensuurset luulet aastaist 1969-1977. Tallinn: Lapin, 1993.

Trapeež 2012 = Albert Trapeež, tema sugulased, sõbrad ja tuttavad. Koostaja Leonhard Lapin. Tallinn: Eesti Keele Sihtasutus.
Unt, Kersti 1999. Muutuv kaanon ja eesti alternatiivluule. - Looming, $\mathrm{nr} 8$, lk 1230-1237.

Unt 2012 = Seilates sadamata. Omakirjastus okupeeritud Eestis. Koostanud Kersti Unt ja Marja Unt. Tallinn: Varrak.

V a rblane, Hannes 2013. Almanakkide aegu. - Keel ja Kirjandus, nr 1, lk 65-69.

Vels ke r, Mart 1999. Mis on kuuekümnendad eesti kirjanduses? - Looming, nr 8, lk 1215-1216.

Ü d i, Jüri ja Vi i d i n g, Juhan 1998. Kogutud luuletused. Koostanud Hasso Krull. Tallinn: Tuum, lk 28-43.

Ü d i, Jüri 2007. Tiibadega raamat. Valinud ja koostanud Hasso Krull. Tallinn: Tänapäev, lk 61-81. 